\title{
Prosthetic valve diphtheroid endocarditis treated with sodium fusidate and erythromycin
}

\author{
Graham Jackson ${ }^{1}$ and Kenneth Saunders \\ From The Brook Hospital, Regional Thoracic Surgical and Cardiac Unit, Shooters Hill Road, London
}

Seven patients with diphtheroid endocarditis after prosthetic valve replacement are reported. Diphtheroids grown from blood cultures should not be dismissed as contaminants without repeated blood cultures, agglutinin, and $L$-form studies. Diphtheroid endocarditis may increase in incidence with the wider use of pre- and postoperative antibiotic prophylaxis, and may be the cause of some examples of endocarditis with 'negative' blood cultures. Four patients survived on a regimen of sodium fusidate (Fucidin) and erythromycin.

The incidence of bacterial endocarditis after open heart surgery is approximately $\mathrm{I}$ per cent, and the mortality is between 50 and 75 per cent (Shafer and Hall, 1970; Denton et al., 1957), though a more aggressive surgical approach may reduce this (English and Ross, 1972; Hairston and Lee, 1970). Diphtheroids are an uncommon cause of bacterial endocarditis and were either not found among the causative organisms or were present in 2 per cent or less of cases (Vogler, Dorney, and Bridges, 1962; English and Ross, 1972; Shafer and Hall, 1970; Stein, Harken, and Dexter, I966; Hairston and Lee, 1970).

Of 47 case reports of diphtheroid endocarditis only 12 were fully proven (Reid and Greenwood, 1967). Since then further reports have been made (Johnson et al., 1968; Thomas and Heilbrunn, 197I).

We report here 7 cases which are of interest because of the difficulty in deciding the pathogenicity of the organism, the problems of finding a suitable antibiotic or antibiotic combination, and the possibility that diphtheroid endocarditis is more common than at present recognized. As far as we are aware this is the first report of combined treatment with sodium fusidate (Fucidin) and erythromycin.

\section{Case reports}

The bacteriology is discussed separately and summarized in Tables 2 and 3. The case histories are summarized in Table I.

\section{Case I}

A woman aged 58 years had an aortic valve replacement Received 2 April 1973.

1 Present address: Cardiac Department, King's College Hospital, Denmark Hill, London SE5 9RS. in February 1966 for aortic stenosis. A Starr-Edwards prosthesis was inserted. Ampicillin was started preoperatively and cloxacillin was added postoperatively. She was discharged five weeks later. She was readmitted one month later with a two-week history of feeling chilly and sweating; temperature was $38^{\circ} \mathrm{C}$. She was jaundiced, anaemic, and had newly-developed clubbing. An early diastolic murmur was heard in the third left intercostal space. Blood cultures grew diphtheroids, but were initially thought to be contaminants. She was started on ampicillin and cloxacillin, but on obtaining further culture results, oral erythromycin $250 \mathrm{mg}$ and sodium fusidate $250 \mathrm{mg}$ were begun, both 6-hourly. She had been afebrile for three days when she died suddenly in the middle of May. At necropsy the aortic valve was infected and the prosthesis had become detached at one point; diphtheroids were grown from the valve ring.

\section{Case 2}

A woman aged 57 years had a mitral valve replacement in April 1970 for mitral incompetence and stenosis. A StarrEdwards prosthesis was inserted. She was discharged four weeks later. In June she was readmitted with malaise and shivering; temperature was $38^{\circ} \mathrm{C}$. She developed rigors, a left facial weakness, and splinter haemorrhages. Auscultation was normal. Diphtheroids were grown from blood cultures. Treatment was started with sodium fusidate I $\mathbf{g}$ and erythromycin I $\mathbf{g}$, 12-hourly parenterally. After an initial favourable response she deteriorated. She developed tunnel vision which resolved on stopping the treatment. Her progress was complicated by an embolus of the femoral artery which was removed by a Fogarty catheter. The clot was infected with diphtheroids (Fig. I and 2). She died suddenly one week later.

At necropsy the prosthesis was the site of extensive vegetations which had almost occluded the orifice of the valve. Laterally there was a mural abscess from which diphtheroids were grown. 
TABLE I Case reports

\begin{tabular}{|c|c|c|c|c|c|c|c|c|}
\hline $\begin{array}{l}\text { Case } \\
\text { No. }\end{array}$ & Sex & $\begin{array}{l}\text { Age } \\
(y r)\end{array}$ & Operation & $\begin{array}{l}\text { Blood } \\
\text { cultures } \\
\text { diphtheroids } \\
\text { No. of bottles }\end{array}$ & $\begin{array}{l}\text { Other } \\
\text { organisms } \\
\text { in blood } \\
\text { cultures }\end{array}$ & $\begin{array}{l}\text { Operative } \\
\text { prophylaxis }\end{array}$ & $\begin{array}{l}\text { Treatment of } \\
\text { endocarditis }\end{array}$ & Outcome \\
\hline I & $\mathrm{F}$ & 58 & $\begin{array}{l}\text { Aortic valve } \\
\text { replacement }\end{array}$ & 3 & None & $\begin{array}{l}\text { Ampicillin } \\
\text { and } \\
\text { cloxacillin }\end{array}$ & $\begin{array}{l}\text { Sodium fusidate and } \\
\text { erythromycin }\end{array}$ & $\begin{array}{l}\text { Remained ill; died } \\
\text { suddenly; diph- } \\
\text { theroids grown at } \\
\text { necropsy }\end{array}$ \\
\hline 2 & $\mathrm{~F}$ & 57 & $\begin{array}{l}\text { Mitral valve } \\
\text { replacement }\end{array}$ & 9 & $\begin{array}{l}\text { Esch. coli I } \\
\text { Strep. fae- } \\
\text { calis I } \\
\text { Micrococ- } \\
\text { cus I }\end{array}$ & $\begin{array}{l}\text { Ampicillin } \\
\text { and } \\
\text { cloxacillin }\end{array}$ & $\begin{array}{l}\text { (1) Penicillin and car- } \\
\text { benicillin for } 2 \text { weeks; } \\
\text { (2) sodium fusidate } \\
\text { and erythromycin; in } \\
\text { last } 2 \text { weeks strepto- } \\
\text { mycin replaced } \\
\text { sodium fusidate due } \\
\text { to side effects }\end{array}$ & $\begin{array}{l}\text { Diphtheroid femoral } \\
\text { embolus; death; } \\
\text { diphtheroids grown } \\
\text { at necropsy }\end{array}$ \\
\hline 3 & F & 44 & $\begin{array}{l}\text { Mitral valve } \\
\text { replacement }\end{array}$ & 5 & None & $\begin{array}{l}\text { Ampicillin } \\
\text { and } \\
\text { cloxacillin }\end{array}$ & $\begin{array}{l}\text { (1) Ampicillin for } 7 \\
\text { days; } \\
\text { (2) sodium fusidate and } \\
\text { penicillin for } 7 \text { days; } \\
\text { (3) sodium fusidate } \\
\text { and erythromycin }\end{array}$ & $\begin{array}{l}\text { No response } \\
\text { No response } \\
\text { Full recovery; died I5 } \\
\text { months later; un- } \\
\text { related cause; no } \\
\text { infection at necropsy }\end{array}$ \\
\hline 4 & $\mathbf{F}$ & 31 & $\begin{array}{l}\text { Aortic valve } \\
\text { replacement }\end{array}$ & 5 & None & $\begin{array}{l}\text { Ampicillin } \\
\text { and } \\
\text { cloxacillin }\end{array}$ & $\begin{array}{l}\text { Sodium fusidate and } \\
\text { erythromycin }\end{array}$ & $\begin{array}{l}\text { (1) Initial recovery; } \\
\text { (2) ruptured splenic } \\
\text { aneurysm; recovered } \\
\text { and discharged; } \\
\text { (3) died; blood } \\
\text { cultures sterile }\end{array}$ \\
\hline 5 & $\mathbf{F}$ & 47 & $\begin{array}{l}\text { Aortic and } \\
\text { mitral valve } \\
\text { replacements }\end{array}$ & I & $\begin{array}{l}\text { Strep. } \\
\text { faecalis } \\
3 \text { bottles }\end{array}$ & Cephalothin & $\begin{array}{l}\text { Sodium fusidate and } \\
\text { erythromycin }\end{array}$ & Full recovery \\
\hline 6 & $\mathbf{M}$ & 43 & $\begin{array}{l}\text { Aortic valve } \\
\text { replacement }\end{array}$ & $\mathbf{I}$ & None & $\begin{array}{l}\text { Ampicillin } \\
\text { and } \\
\text { cloxacillin }\end{array}$ & $\begin{array}{l}\text { Sodium fusidate and } \\
\text { erythromycin }\end{array}$ & Full recovery \\
\hline 7 & $\mathbf{M}$ & 40 & $\begin{array}{l}\text { Mitral valve } \\
\text { replacement }\end{array}$ & I5 & None & $\begin{array}{l}\text { Ampicillin } \\
\text { and } \\
\text { cloxacillin }\end{array}$ & $\begin{array}{l}\text { (1) Penicillin for Io } \\
\text { days; } \\
\text { (2) sodium fusidate } \\
\text { and erythromycin }\end{array}$ & $\begin{array}{l}\text { No response } \\
\text { Full recovery }\end{array}$ \\
\hline
\end{tabular}

\section{Case 3}

A woman aged 44 years had a mitral valve replacement in November 1968 for mitral incompetence. A StarrEdwards disc prosthesis was inserted. Ampicillin and cloxacillin were given prophylactically. She was discharged in January 1969. She was readmitted in May with a three-week history of anorexia, nausea, intermittent vomiting, and a cough; temperature was $38^{\circ} \mathrm{C}$. Diphtheroids were grown from blood cultures and sodium fusidate I $\mathbf{g}$ and penicillin $\mathrm{I} \mathbf{g}$ were started 12 -hourly intravenously. Her fever failed to resolve but after changing the penicillin for erythromycin, the fever remitted and she improved. Therapy was continued with oral sodium fusidate 500 $\mathrm{mg}$ and erythromycin $500 \mathrm{mg}$ both 6-hourly. An early diastolic murmur was heard for the first time two weeks after admission. She continued erythromycin for four months after her discharge. She attended hospital as an outpatient and remained well until she died from a cerebral haemorrhage Is months later. Necropsy revealed no residual infection.

\section{Case 4}

A woman aged 3I years had an aortic valve replacement in April I97I for rheumatic aortic incompetence. A Starr-Edwards prosthesis was inserted. Ampicillin and cloxacillin were given pre- and postoperatively. She was discharged 3 weeks later. She was readmitted in July with a 2-week history of fatigue, anorexia, and nausea. She was pale and ill. Auscultation revealed no valvar leak. She was tender on deep palpation in the left loin, but no spleen or kidney was felt. Her temperature rose to $39 \cdot 5^{\circ} \mathrm{C}$. Blood cultures grew diphtheroids. She was given sodium fusidate $500 \mathrm{mg}$ and erythromycin $500 \mathrm{mg}$ both orally 6-hourly, and she became apyrexial and improved. However, suddenly in August she developed an acute abdominal pain and collapsed with profound 


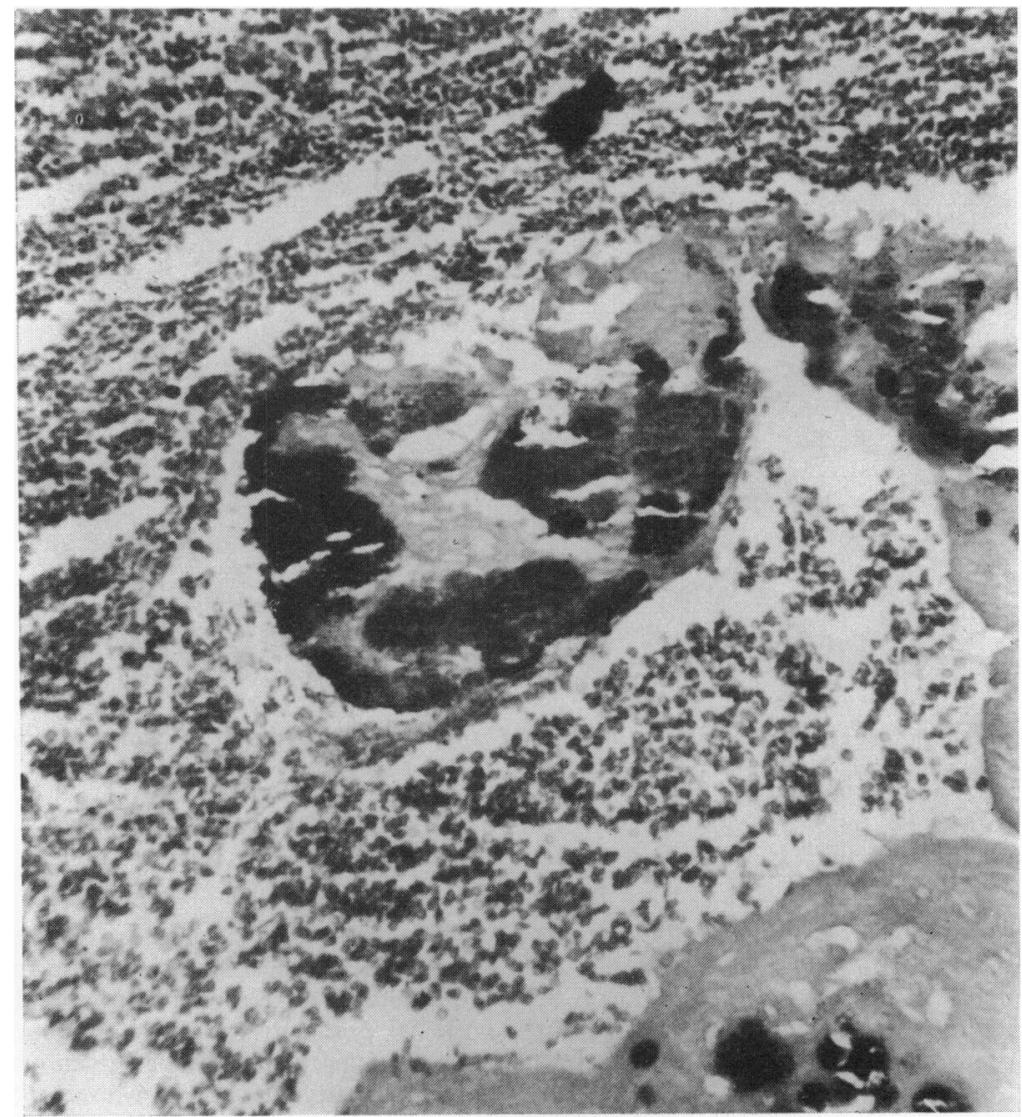

FIG. I Section of diphtheroid femoral embolus. The black irregular areas at the centre consist of colonies of Gram-positive bacilli. ( $\times 600$.)

TABLE 2 Antibiotic sensitivity

\begin{tabular}{llllllll}
\hline & \multicolumn{9}{c}{ Case No. } \\
Antibiotics & I & 2 & 3 & 4 & S & 6 & 7 \\
\hline Methicillin & R & S & S & R & R & S & S \\
Penicillin & R & S & S & R & R & S & S \\
Tetracycline & S & S & S & S & S & S & S \\
Lincomycin & S & S & S & S & S & S & S \\
Erythromycin & S & S & S & S & S & S & S \\
Ampicillin & R & S & S & R & R & S & S \\
Kanamycin & S & S & S & - & S & S & S \\
Sulphonamide & R & S & R & - & S & R & S \\
Colomycin & R & I & R & - & R & S & R \\
Septrin & - & S & R & - & S & R & - \\
Cephalothin & - & S & S & S & S & - & - \\
Sodium fusidate & S & S & S & S & S & S & S \\
Streptomycin & S & S & R & - & S & - & S \\
Carbenicillin & I & S & S & - & S & - & - \\
Chlorarnphenicol & S & S & S & - & S & - & S \\
Gentamycin & - & - & S & - & - & - & S \\
\hline
\end{tabular}

$-=$ Not performed. $\mathbf{S}=$ Sensitive. $\quad \mathbf{R}=$ Resistant. hypotension. She had a rigid, tender abdomen silent to auscultation. After resuscitation she was explored by Mr. M. Rosenberg who found a ruptured mycotic splenic aneurysm and an infected spleen from which diphtheroids were cultured. Splenectomy and vessel ligation were carried out. Postoperatively she was continued on sodium fusidate and erythromycin intravenously and then orally. She was discharged well in September continuing her antibiotics. She was readmitted two months later with lethargy, anorexia, and blurring of vision. She now had an early diastolic murmur and finger clubbing. Blood cultures were sterile. She deteriorated and the patient and relatives wished no surgical intervention. She died in November. Permission was not granted for necropsy.

\section{Case 5}

A woman aged 47 years had aortic and mitral valve replacements in January $197 \mathrm{I}$ for rheumatic valvar disease. Starr-Edwards aortic and mitral prostheses were inserted. 


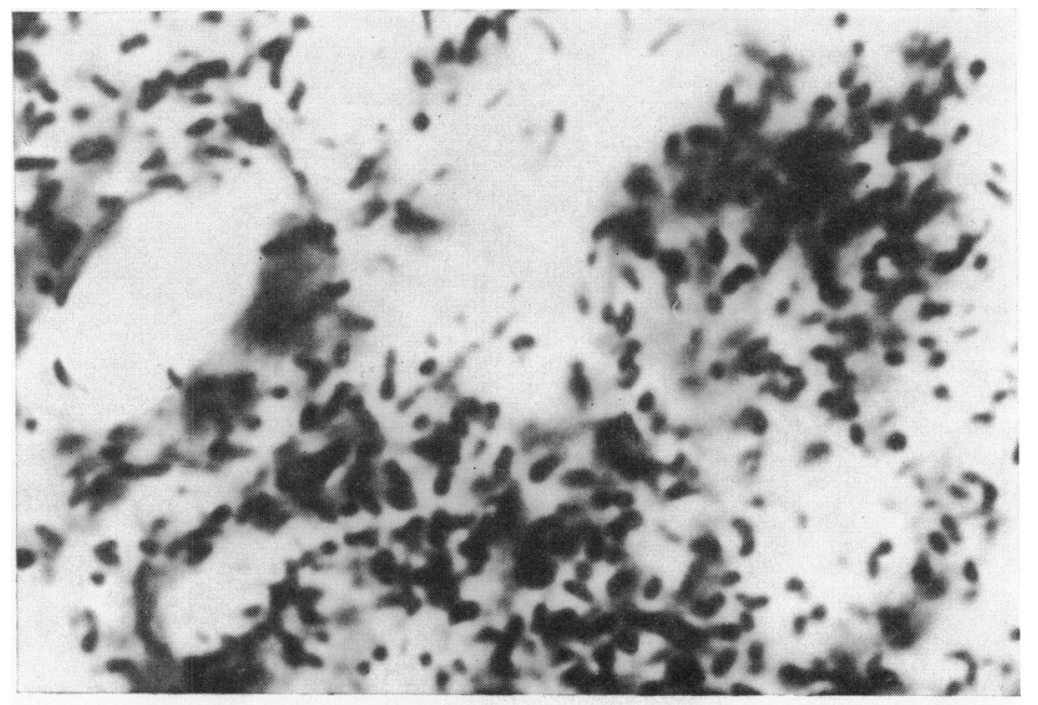

FIG. 2 High-power view $(\times 4350)$ of one of the areas of Fig. I to show Gram-positive organisms.

Cephalothin (Keflin) was given prophylactically. She was discharged a month later. She was readmitted in May with a history of malaise, headache, nausea, and fever. Blood cultures at the referring hospital were sterile, but she was treated with intravenous penicillin $12 \mathrm{~g}$ and clox-

TABLE 3 Cultural and biochemical characteristics of four organisms

\begin{tabular}{|c|c|c|c|c|}
\hline & Case 3 & Case 4 & Case 5 & Case 7 \\
\hline Catalase & + & + & - & + \\
\hline Oxidase & + & 0 & O & 0 \\
\hline Growth at $22^{\circ} \mathrm{C}$ & + & O & + & 0 \\
\hline Indole & - & $\mathbf{O}$ & o & O \\
\hline Kinase & - & 0 & O & 0 \\
\hline Tellurite & + & o & + & + \\
\hline Nutrient agar & + & O & O & 0 \\
\hline Nutrient broth & $\begin{array}{l}\text { Surface/ } \\
\text { deposit }\end{array}$ & 0 & O & $\mathbf{O}$ \\
\hline Gelatin & - & - & - & 0 \\
\hline Glucose & Acid & Acid & Acid & Acid \\
\hline Maltose & Acid & Acid & - & Acid \\
\hline Dulcite & - & - & $\mathbf{O}$ & Acid \\
\hline Sucrose & - & - & - & - \\
\hline Lactose & - & - & - & - \\
\hline Starch & - & - & 0 & - \\
\hline Salicin & - & - & 0 & - \\
\hline $\begin{array}{l}\text { Toxin production } \\
\text { (Eleks method) }\end{array}$ & - & - & - & - \\
\hline
\end{tabular}

$+=$ Positive.

$-=$ Negative.

$\mathrm{O}=$ Not performed. acillin I $\mathrm{g}$ daily for 9 days before transfer. On examination she appeared well, but was anaemic and had haematuria. Diphtheroids were grown from one blood culture, along with Streptococcus faecalis. Agglutinins to diphtheroids were demonstrated. She was given oral sodium fusidate and erythromycin $500 \mathrm{mg}$ 6-hourly. She made a rapid recovery. Antibiotics were discontinued in September. When seen the following April she was fully active with no evidence of valvar regurgitation.

\section{Case 6}

A man aged 38 had an aortic valve replacement in 1964 . He remained well until 1968 when after bacterial endocarditis he had a further aortic valve replacement. Blood cultures were negative. A Starr-Edwards prosthesis was inserted. He received ampicillin and cloxacillin pre- and postoperatively. He was discharged in December 1968.

In December 1971 he was admitted with a 2-month history of pallor, fatigue, and dyspnoea. He was anaemic. No valvar leak was heard. Diphtheroids were isolated from one blood culture and a high agglutinin titre was demonstrated. He had a low grade pyrexia which resolved after starting erythromycin $500 \mathrm{mg}$ and sodium fusidate $500 \mathrm{mg}$ orally both 6-hourly. He made rapid progress and his antibiotics were discontinued in August 1972. He was seen in October 1972 and is well.

\section{Case 7}

A man aged 40 years had a mitral valve replacement in September 1969 for rheumatic mitral incompetence and 
stenosis. A Starr-Edwards mitral prosthesis was inserted. Ampicillin and cloxacillin were given pre- and postoperatively. He was discharged in October. He was readmitted 2 months later with a 2 -week influenza-like illness; temperature was $38^{\circ} \mathrm{C}$. He had had haematuria, anorexia, rigors, and sweating attacks for 5 days. He was anaemic, had splinter haemorrhages, and a pansystolic murmur at the apex. Diphtheroids were grown from blood cultures. He received penicillin with no improvement, but after culture sensitivities he was given erythromycin $500 \mathrm{mg}$ and sodium fusidate $500 \mathrm{mg}$ both orally 6-hourly. He developed left hypochondrial pain which was thought to be a splenic infarct. An episode of pulmonary oedema was controlled. One week after starting erythromycin and sodium fusidate he was apyrexial and improved. He was discharged in February 1970.

He was last seen in outpatients in September 1972 and was fully active, with no signs of valvar regurgitation.

\section{Bacteriology \\ Materials and methods}

Blood cultures were taken routinely into glucose broth with added para-aminobenzoic acid and penicillinase, and in some instances also into glucose broth with 'liquoid' added, Brewer's thioglycollate medium, and Robertson's cooked meat medium containing penicillinase. These were incubated for 48 hours when a first subculture was made onto blood agar and incubated aerobically, anaerobically, and in to per cent carbon dioxide. The original cultures were again subcultured at 7 days, I4 days, and 21 days incubation.

\section{Morphology}

All organisms were Gram-positive, non-motile, noncapsulated bacilli. Some were arranged in Chinese letters on a Gram stain smear and some showed irregular staining by Albert's method. Some of the strains were very short and oval in shape. Four of the strains were studied in detail and two were examined at the National Collection of Type Cultures. The cultural and biochemical characteristics of these are shown in Table 3.

The identification of the strain from Case 5 was Coryne bacterium pyogenes var hominis and in Case 4, Coryne bacterium bovis. A subsequent communication cast some doubt on the identity of Case 5's strain, because in the staphylococcal alpha/beta lysin inhibition test the strain failed to inhibit the lysins. We demonstrated high titres of agglutinins to the diphtheroid organisms in Cases 5, 6, and 7 .

In all cases the organism was not recovered from blood culture for 5 to 7 days: this may have been due to preoperative antibiotic prophylaxis. It was later shown that the organisms were slow growing and micro-aerophilic. In one case an unsuccessful attempt was made to isolate diphtheroids on special media for the growth of bacteria with defective cell walls, namely L-forms. The antibiotic sensitivities are shown in Table 2.

\section{Therapeutic rationale}

The initial management was with penicillin. When blood culture reports were received the antibiotic combination of sodium fusidate and erythromycin was started. All strains were sensitive and a bacteriocidal concentration was in the therapeutic range of sodium fusidate. Erythromycin was combined with sodium fusidate for three main reasons. All the organisms were sensitive; there is evidence of synergy between the two antibiotics (Garrod and O'Grady, 1972) and on the theoretical grounds that if any $L$-forms had been induced these would be susceptible. The presence of $L$-forms in endocarditis has been shown by Wittler et al. (1960).

\section{Side effects of sodium fusidate and erythro- mycin regimen}

We encountered gastrointestinal side effects which were cured with antidiarrhoeal agents. One patient developed tunnel vision which resolved after sodium fusidate was withdrawn; this has not been described before.

We do not feel that gastrointestinal upsets should cause discontinuance of these antibiotics. On each occasion we successfully dealt with the problem, resorting to temporary intravenous therapy if necessary. Subsequently we have started a lactobacillus preparation simultaneously with the oral antibiotics, adding codeine phosphate if needed.

\section{Discussion}

Diphtheroid endocarditis has been successfully treated with bacitracin (Zendel and Lubart, 1952), and penicillin with streptomycin (Levin, I966), but is usually relatively resistant to penicillin alone or penicillin combined with ampicillin or cloxacillin. The prophylactic use of ampicillin and cloxacillin may lead to resistant diphtheroids and L-forms and an increased incidence of diphtheroid endocarditis. It is important not to dismiss diphtheroids as contaminants without further study.

The criteria of acceptance of a diphtheroid as a pathogenic organism are difficult. The diagnosis relies on blood cultures and the demonstration of agglutinins. All except two cases had multiple positive cultures. Case 5 had a very high agglutinin titre and we considered the diphtheroid to be jointly infective with streptococcus faecalis. Case 6 had a high agglutinin titre also.

The overall mortality from diphtheroid endocarditis appears to be higher than in that of other infective agents, and the survival of 4 out of 7 patients in this series is encouraging. In retrospect we consider we should have sought surgical help earlier in our management, but it is only recently that early reoperation has been proved successful (English and Ross, 1972; Hairston and Lee, 1970). Case 2 remained ill throughout her treatment and necropsy revealed almost complete occlusion of the valve by 
vegetations. With Case 4 our advice to reoperate was rejected by the patient and her relatives. Our first case was initially undiagnosed. She remained ill throughout and we decided that the risk of reoperation was unacceptable. This may have been an error on our part but in 1966 emergency operation for endocarditis was not a routine procedure.

Six cases were of late onset. In one patient our pre- and post-operative bacteriological studies revealed diphtheroids in a wound swab. We cultured all theatre equipment and staff and could find no obvious origin for the infections. Diphtheroid organisms are ubiquitous and many external sources of contamination exist, which were the most likely cause of infection in our cases. It is possible that repeated venepuncture in anticoagulant clinics could be a source (B. P. Moore, 1973, personal communication). The patient with a valve prosthesis is vulnerable to infection because of the presence of foreign material, the prolonged exposure time in cardiac surgery, and the alteration of bacterial flora caused by prophylactic antibiotics. Bacteraemia is common in normal subjects and in these vulnerable groups may cause endocarditis (Barney et al., 1962). All patients with valve replacements need antibiotic cover for any procedure.

Two patients are particularly interesting. Case 2 had a femoral embolus which contained a heavy growth of diphtheroids; we have not seen a previous description of this event. Case 4 had a ruptured mycotic splenic aneurysm. Aortopulmonary fistula (Thomas and Heilbrunn, I97I) and left coronary sinus aneurysm (Johnson et al., 1968) have been recorded previously, but to our knowledge this represents the first reported case of a ruptured mycotic splenic aneurysm caused by diphtheroids.

In conclusion, therefore, diphtheroid endocarditis presents a difficult diagnostic problem by virtue of both the slow growth of diphtheroids on culture and also their doubtful pathogenicity. Prosthetic valves are particularly susceptible to diphtheroid infection. Sodium fusidate and erythromycin in combination have proved efficacious in 4 of our 7 patients. Throughout medical therapy the cardiologist must work in close co-ordination with the bacteriologist and surgeon and emergency surgery must be pursued promptly (Hairston and Lee, 1970).
L. R. Hill, Esq., Deputy Curator National Collection of Type Cultures, assisted us with organism identification. Mr. B. Moore, Mr. A. Macarthur, and Mr. R. Burn allowed us to report cases they operated on. We thank Dr. Ronald Hartley and Dr. Max Zoob for their overall supervision of the patients and P. Rambran for technical assistance.

\section{References}

Barney, J. D., Williams, G. R., Cayler, G. G., and Bracken, E. C. (1962). Influence of intracardiac prosthetic materials on susceptibility to bacterial endocarditis. Circulation, 26, 684.

Denton, C., Pappas, E. G., Uricchio, J. F., Goldberg, H., and Likoff, W. (1957). Bacterial endocarditis following cardiac surgery. Circulation, 15, 525.

English, T. A. H., and Ross, J. K. (1972). Surgical aspects of bacterial endocarditis. British Medical fournal, 4, 598.

Garrod, L. P., and O'Grady, F. (1972). Antibiotic and Chemotherapy, 3rd ed. E. and S. Livingstone, London.

Hairston, P., and Lee, W. H. (1970). Management of infected prosthetic heart valves. Annals of Thoracic Surgery, 9, 229.

Johnson, W. D., Cobbs, C. G., Arditi, L. I., and Kaye, D. (1968). Diphtheroid endocarditis after insertion of a prosthetic heart valve. Fournal of the American Medical Association, 203, 919.

Levin, J. (1966). Diphtheroid bacterial endocarditis after insertion of a Starr valve. Annals of Internal Medicine, 64, 396.

Reid, J. D., and Greenwood, L. (1967). Corynebacterial endocarditis. Archives of Internal Medicine, 119, 106.

Shafer, R. B., and Hall, W. H. (1970). Bacterial endocarditis following open heart surgery. American fournal of Cardiology, 25, 602 .

Stein, P. D., Harken, D. E., and Dexter, L. (I966). The nature and prevention of prosthetic valve endocarditis. American Heart fournal, 71, 393.

Thomas, T. V., and Heilbrunn, A. (197I). Prosthetic aortic valve replacement complicated by diphtheroid endocarditis and aortopulmonary fistula. Chest, 59, 679.

Vogler, W. R., Dorney, E. R., and Bridges, H. A. (I962). Bacterial endocarditis. A review of 148 cases. American fournal of Medicine, 32, $9 \mathrm{IO}$.

Wittler, R. G., Malizia, W. F., Kramer, P. E., Tuckett, J. D., Pritchard, H. N., and Baker, H. J. (1960). Isolation of a corynebacterium and its transitional forms from a case of subacute bacterial endocarditis treated with antibiotics. fournal of General Microbiology, 23, 315.

Zendel, J. F., and Lubart, A. (1952). Diphtheroid subacute endocarditis successfully treated with bacitracin. Archives of Internal Medicine, 90, 562 .

Requests for reprints to Dr. Graham Jackson, Cardiac Department, King's College Hospital, Denmark Hill, London SE5 9RS. 